\title{
ASSESSMENT OF THE STRUCTURE AND DIVERSITY OF LATVIAN ACER PLATANOIDES POPULATIONS USING CROSS-SPECIES NUCLEAR MICROSATELLITE MARKERS
}

\author{
Dainis Edgars Rung̣is" ${ }^{\#}$ and Baiba Krivmane \\ Latvian State Forest Research Institute "Silava", 111 Rïgas Str., Salaspils, LV-2169, Latvia \\ \# Corresponding author, dainis.rungis@silava.Iv
}

Contributed by Dainis Ruṇǵis

\begin{abstract}
Acer platanoides L. (Norway maple) is the most widespread native maple species in Europe, with a distribution from south and central Europe to northern Europe and Scandinavia. Acer platanoides is widespread throughout the territory of Latvia, and is mainly found in mixed broadleaf and conifer stands. The genetic diversity and differentiation of Latvian A. platanoides populations was analysed. Sampled populations were located throughout the territory of Latvia, and were selected to represent a range of ecological conditions, with differing levels of anthropogenic impact. A total of 496 individuals from 21 populations were analysed with eight microsatellite markers, which were developed from related Acer species. The obtained molecular data revealed a moderate level of polymorphism, and the analysed Latvian A. platanoides populations were moderately differentiated. This study provides an initial assessment of the genetic diversity and differentiation of Latvian A. platanoides populations, and is also one of the first reports of the analysis of A. platanoides populations using microsatellite markers. The results can be utilised to define A. platanoides genetic resource stands to ensure conservation of a wide range of germplasm.
\end{abstract}

Keywords: Norway maple, genetic resources, population genetics.

\section{INTRODUCTION}

Acer platanoides L. (Norway maple) is the most widespread native maple species in Europe, with its natural distribution ranging from Greece, Balkans, Northern Italy and the Pyrenees to southern Fennoscandia, and toward the East up to the Ural Mountains. It is not native to western France, the UK, the Netherlands and Denmark. This species can grow in a wide range of soils and habitat conditions, from sea level up to $1400 \mathrm{~m}$ elevation (Caudulloa and de Rigo, 2016).

A. platanoides is monoecious, with individuals bearing both male and female flowers, which are mainly insect pollinated. Seeds are medium-sized, with double samaras, and are wind-dispersed. There is little evidence of vegetative reproduction. A study of characteristics of A. platanoides and A. pseudoplatanus seeds collected along a $2200 \mathrm{~km}$ long latitudinal gradient from Italy to Norway indicated that the seed mass of A. platanoides was negatively influenced by increasing temperatures, and that seed viability was related to seed mass, with larger seeds having higher viability
(Carón et al., 2014). Seeds of A. pseudoplatanus were less influenced by climactic factors. This indicates that seeds of northern A. platanoides populations are currently of higher quality than those of southern and central origin; however, climate change can potentially have a relatively negative effect on seed quality.

Acer platanoides is widespread throughout the territory of Latvia. The largest areas are found in eastern regions, with the largest proportion of the total stand area found in the Latgale Highlands (364.8 ha, 16.3\%) and Augšzeme (235.6 ha, $10.5 \%$ ). A substantial proportion also grows in the coastal lowlands ( 222.7 ha, $10.0 \%$ ), but in this region stands are typical of urban (Rīga, Jūrmala, Ventspils) and suburban forests. A. platanoides forest stands are characteristic in nutrient-rich mineral soil sites - Oxalidos, Hylocomiosa, Aegopodiosa forest types ( $88.9 \%$ of total area). A. platanoides is mainly found in mixed broadleaf and conifer stands. Currently, A. platanoides reproduces very intensively in extensively managed broadleaf and coniferous forests, especially in pine stands, as well as in urban and suburban environments (urban forests), which indicates the ruderal or 
pioneer species strategy of A. platanoides. Under current changing environmental conditions, maple is a typical colonising species of broad-leaved forest stands in Latvia. A. platanoides individuals in forest stands are of different ages, and are not characterised by the formation of multi-story stands, renewal is gradual and stands contain a continuum of individuals by age.

Currently, there are very few studies of the genetic diversity and population structure of $A$. platanoides. Two studies utilised isozyme markers to analyse A. platanoides in Finland (Rusanen et al., 2000), and A. platanoides populations in northern Europe (Rusanen et al., 2003). The latter study compared genetic diversity and population differentiation between central and marginal populations of A. platanoides. Contrary to expectations, there was no difference in the genetic diversity between central and marginal populations, and the marginal populations were less differentiated than the central populations. This result was related to postglacial climate changes and the vegetation history in northern Europe, and the current marginal population distribution is a result of the contraction of a previously continuously distributed population rather than an expansion from the distribution centre. Therefore, fragmentation of northern marginal populations occurred too recently for genetic drift to have an impact on the diversity and differentiation of these populations. In addition, anthropogenic impacts have been more prolonged and extensive in central European populations (Rusanen et al., 2003).

DNA markers can provide valuable additional information about the diversity and structure of populations. They are often more informative than phenotypic parameters, as they are not influenced by environmental conditions, and can be assessed at any stage of the growing season or life cycle. Microsatellites or simple sequence repeat (SSR) markers are widely utilised for population genetic studies, as they are highly polymorphic, and are codominant, which enable direct quantification of heterozygosity. One major drawback is that they need to be developed for each locus, by characterising DNA sequences surrounding the repeat regions, which entails considerable time and effort. Microsatellite markers are predominantly species specific, but can be transferred to related species. However, transfer to other species can result in amplification of non-specific PCR products or null alleles. Null alleles occur when there is a mutation in the primer binding sites in some alleles, leading to a lack of PCR amplification of these alleles. The presence of null alleles can be inferred by comparison of observed and expected heterozygosities, assuming the analysed populations are in Hardy-Weinberg equilibrium. In addition, often lower levels of diversity are revealed by microsatellite markers in species other than those from which they were developed. No microsatellite markers have been developed for A. platanoides so far, but microsatellite markers have been developed for A. pseudoplatanus (Pandey et al., 2004), A. miyabei and A. saccharum (Harmon et al., 2017). Both sets of markers were tested in a range of Acer species, and a proportion of these markers were reported to amplify PCR products from $A$. platanoides.
The aim of this study was to analyse the genetic diversity and differentiation of Latvian A. platanoides populations. The analysed populations were located throughout the territory of Latvia, and were selected to represent a range of ecological conditions, with mixed stands consisting of different species, both broadleaf and coniferous, as well as differing levels of anthropogenic impact. The results can be utilised to define A. platanoides genetic resource stands to ensure conservation of a wide range of germplasm.

\section{MATERIALS AND METHODS}

Analysed populations and sample collection. Samples for DNA extraction were collected from $21 \mathrm{~A}$. platanoides plots located throughout the territory of Latvia. Leaf or twig samples were collected from 24 individuals from each plot. A total of 504 individuals were collected from 21 populations (Fig. 1, Table 1).

DNA was extracted using a modified CTAB method (Doyle and Doyle, 1990). A total of 15 microsatellite markers were used to genotype the sampled individuals: As_di1, As_di9, As_di15, As_di21, As_di49, As_tetra1 (Harmon et al., 2017); MAP2, MAP9, MAP10, MAP12, MAP33, MAP40, MAP46 (Pandey et al., 2004); Acmi11, Acmi33 (Saeki et $a l ., 2015)$. None of these markers were developed specifically for A. platanoides, but were derived from sugar maple (Acer saccharum Marsh.) (Harmon et al., 2017), sycamore (Acer pseudoplatanus L.) (Pandey et al., 2004) and Acer miyabei Maxim. (Saeki et al., 2015).

PCR reactions were performed in a volume of $10 \mu \mathrm{l}$ containing approximately $50 \mathrm{ng}$ DNA, $2 \mu \mathrm{l}$ HOT FIREPol ${ }^{\circledR}$ Blend Master Mix (Solis BioDyne) (containing $10 \mathrm{mM}$ $\mathrm{MgCl}_{2}$ ), $0.3 \mu \mathrm{M}$ forward and reverse primers. PCR was carried out in a thermocycler (Eppendorf Mastercycler epgradient) using the following protocol: initial predenaturation step at $95{ }^{\circ} \mathrm{C}$ for $15 \mathrm{~min}$, followed by 35 cycles of $95^{\circ} \mathrm{C}$ for $30 \mathrm{~s}, 60{ }^{\circ} \mathrm{C}$ for $30 \mathrm{~s}$, and $72{ }^{\circ} \mathrm{C}$ for $40 \mathrm{~s}$ and a final extension step of $72{ }^{\circ} \mathrm{C}$ for 10 min for all markers with the exception of Map2, Map10, Map33: Map9, Map40, Map46: AsTetra, Acmi33, Map12, where the annealing temperature was 55 ${ }^{\circ} \mathrm{C}$. All PCR reaction products were diluted 1: 10 with

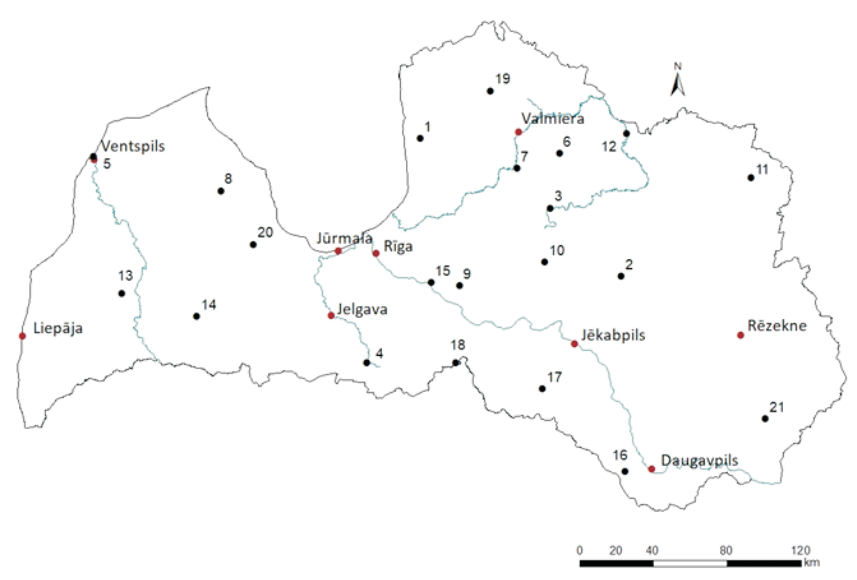

Fig. 1. Analysed A. platanoides population in Latvia (black dots - site numbering as in Table 1) 
Table 1. Details of analysed A. platanoides populations

\begin{tabular}{|c|c|c|c|c|c|}
\hline No. & Name & Stand species compostion/description & $\begin{array}{c}\text { Anthropogenic } \\
\text { impact }\end{array}$ & Region & Coordinates \\
\hline 1 & Limbaži & A. platanoides (with Fraxinus excelsior) & Low & Eastern & $57.517,24.528$ \\
\hline 2 & Madona & Pinus sylvestris with A. platanoides in 2 nd storey & Medium & Eastern & $56.826,26.306$ \\
\hline 3 & Taurene & Picea abies & Low & Eastern & $57.166,25.692$ \\
\hline 4 & Rundāle & A. platanoides (with Fraxinus excelsior) & Low & Western & $56.422,24.043$ \\
\hline 5 & Ventspils & Pinus sylvestris with $A$. platanoides & High & Western & $57.405,21.573$ \\
\hline 6 & Smiltene & Undergrowth beneath Betula and other broadleaf species & Low & Eastern & $57.433,25.785$ \\
\hline 7 & Priekuḷi & Pinus sylvestris with $A$. platanoides in 2 nd storey & Low & Eastern & $57.364,25.402$ \\
\hline 8 & Šķēede & Roadside & Medium & Western & $57.256,22.734$ \\
\hline 9 & Glāzšḳūnis & Clearing, rejuvenation with broadleaf species & Medium & Eastern & $56.796,24.869$ \\
\hline 10 & Ërgli & Mixed Pinus sylvestris, Picea abies, Qurcus robur & Medium & Eastern & $56.906,25.632$ \\
\hline 11 & Kuprava & Tilia cordata & Low & Eastern & $57.276,27.500$ \\
\hline 12 & Gaujiena & Pinus sylvestris & High & Eastern & $57.519,26.399$ \\
\hline 13 & Laidi & Mixed broadleaf forest by cemetary & High & Western & $56.742,21.872$ \\
\hline 14 & Saldus & A. platanoides, Picea abies, Quercus robur & Low & Western & $56.641,22.541$ \\
\hline 15 & Ogre & Pinus sylvestris with A. platanoides in 2nd storey & High & Eastern & $56.812,24.615$ \\
\hline 16 & Rauda & A. platanoides juvenile stand & Low & Eastern & $55.873,26.279$ \\
\hline 17 & Klauce & A. platanoides (with Fraxinus excelsior) & Low & Eastern & $56.287,25.583$ \\
\hline 18 & Kurmene & A. platanoides along the River Mēmele & Medium & Eastern & $56.419,24.828$ \\
\hline 19 & Jēkabkalns & A. platanoides and Tilia cordata, old park & High & Eastern & $57.744,25.171$ \\
\hline 20 & Tukums & Abandoned settlement, A. platanoides and Tilia cordata & High & Western & $56.997,23.033$ \\
\hline 21 & Dagda & Shrubbery by cemetery & High & Eastern & $56.102,27.521$ \\
\hline
\end{tabular}

deionised water, and visualised on an Applied Biosystems ABI Prism 3100xl Genetic Analyser. Genotyping was performed using GeneMapper 4.0. (Applied Biosystems). All the MAP markers were monomorphic in the analysed samples, and therefore were not analysed. Individuals with missing data at more than three loci were also removed prior to analysis. As a result, a total of 496 individuals from 21 populations were retained for further analysis.

Micro-Checker 2.2 (Van Oosterhout et al., 2004) was used to identify potential null alleles. GenAlEx 6.501 (Peakall and Smouse, 2012) was used to calculate genetic diversity indices, and AMOVA and pairwise population differentiation $\left(\mathrm{F}_{\mathrm{ST}}\right)$ (using 999 permutations) as well as the probability of identity, which is the probability that two individuals have the same genotype by chance. This can also be calculated taking into account sibling relationships. STRUCTURE 2.3.4 was used to determine clustering of the populations using a 100000 burning period, followed by 150000 MCMC steps, $\mathrm{K}$ was determined for 1 to 21 with 15 runs for each value of $\mathrm{K}$. The LOCPRIOR model was used, using the sampling location as default information to assist clustering, which is recommended for use with datasets with a weak structure signal (Pritchard et al., 2000). The optimal value of $\mathrm{K}$ was determined using the $\Delta \mathrm{K}$ method (Evanno et al., 2005) using STRUCTURE HARVESTER (Earl, 2012) and the probability by $\mathrm{K}$ using median values of $\mathrm{Ln}(\mathrm{Pr}$ Data) implemented via the CLUMPAK server (Kopelman et al., 2015). Coefficients of membership to the most likely K cluster number were visualised using Distruct via the CLUMPAK server.

\section{RESULTS}

The presence of potential null alleles was assessed using Micro-Checker 2.2, and the number of potential null alleles was not high. While loci with potential null alleles were identified in 10 of the 21 analysed populations, most had only one locus with potential null alleles, and the remaining two populations each had two loci with potential null alleles. In addition, only two loci had potential null alleles in more than two populations - As_di2 and As_di49 (in five and three populations, respectively). Therefore, all loci were retained for further analyses.

The genetic diversity parameters of the analysed loci are summarised in Table 2. The total number of alleles at each locus ranged from 4 (As_di15 and As_tetra1) to 15 (As_di49), while the average number of alleles (over all populations) at each locus ranged from 2.14 (As_di15) to 6.48 (As_di49). The fixation index or inbreeding coefficient (F) was negative for most loci, with the exception of As_di1, As_di9 and As_di49. However, as mentioned previously, this heterozygote excess (indicating the potential presence of null alleles) at these loci was not detected in all populations, and so all loci were retained for analyses.

The genetic diversity parameters of the analysed populations are summarised in Table 3 . The average number of alleles (over all loci) ranged from 3.63 (Tukums) to 5.50 (Kurmene). The Madona population also had the lowest values for number of effective alleles (Ne) and information index (I). However, the Škêde population had the highest Ne 
Table 2. Genetic diversity parameters of the analysed loci

\begin{tabular}{|c|c|c|c|c|c|c|c|c|}
\hline & Acmi11 & As_di1 & As_di9 & As_di15 & As_di21 & As_di49 & As_tetra1 & Acmi33 \\
\hline Natot & 12 & 9 & 12 & 4 & 11 & 15 & 4 & 13 \\
\hline $\mathrm{Na}(\mathrm{SE})$ & $3.52(0.18)$ & $3.29(0.20)$ & $4.95(0.19)$ & $2.14(0.10)$ & $5.29(0.24)$ & $6.48(0.24)$ & $3.05(0.05)$ & $6.33(0.31)$ \\
\hline I (SE) & $0.68(0.06)$ & $0.87(0.03)$ & $1.26(0.05)$ & $0.54(0.04)$ & $1.26(0.05)$ & $1.45(0.05)$ & $0.87(0.02)$ & $1.49(0.04)$ \\
\hline Ho (SE) & $0.36(0.03)$ & $0.44(0.03)$ & $0.63(0.02)$ & $0.36(0.04)$ & $0.67(0.03)$ & $0.60(0.04)$ & $0.60(0.03)$ & $0.76(0.03)$ \\
\hline uHe (SE) & $0.37(0.04)$ & $0.55(0.01)$ & $0.67(0.02)$ & $0.36(0.03)$ & $0.65(0.02)$ & $0.71(0.02)$ & $0.55(0.01)$ & $0.74(0.02)$ \\
\hline $\mathrm{F}(\mathrm{SE})$ & $-0.01(0.04)$ & $0.17(0.05)$ & $0.03(0.03)$ & $-0.02(0.05)$ & $-0.06(0.04)$ & $0.13(0.04)$ & $-0.12(0.05)$ & $-0.05(0.03)$ \\
\hline
\end{tabular}

Natot; total number of alleles; Na, average number of alleles over all loci; Ne. average number of effective alleles over all loci; I, average information index over all loci; Ho, average observed heterozygosity over all loci; uHe, average unbiased expected heterozygosity over all loci; F, average inbreeding coefficient over all loci; SE, standard error

Table 3. Genetic diversity parameters of the analysed populations (average values over all analysed loci)

\begin{tabular}{|c|c|c|c|c|c|c|}
\hline & $\mathrm{Na}(\mathrm{SE})$ & $\mathrm{Ne}(\mathrm{SE})$ & $\mathrm{I}(\mathrm{SE})$ & Ho (SE) & $\mathrm{uHe}(\mathrm{SE})$ & $\mathrm{F}(\mathrm{SE})$ \\
\hline Limbaži & $4.00(0.53)$ & $2.33(0.37)$ & $0.93(0.15)$ & $0.48(0.06)$ & $0.51(0.08)$ & $-0.02(0.05)$ \\
\hline Ventspils & $4.00(0.57)$ & $2.51(0.27)$ & $1.02(0.12)$ & $0.50(0.04)$ & $0.58(0.04)$ & $0.10(0.07)$ \\
\hline Madona & $4.25(0.77)$ & $2.09(0.40)$ & $0.85(0.15)$ & $0.48(0.07)$ & $0.45(0.07)$ & $-0.11(0.04)$ \\
\hline Rundāle & $4.00(0.65)$ & $2.80(0.38)$ & $1.08(0.15)$ & $0.62(0.07)$ & $0.61(0.05)$ & $-0.04(0.07)$ \\
\hline Taurene & $4.13(0.55)$ & $2.40(0.24)$ & $1.01(0.10)$ & $0.58(0.05)$ & $0.57(0.04)$ & $-0.04(0.06)$ \\
\hline Priekuḷi & $3.88(0.61)$ & $2.32(0.33)$ & $0.90(0.15)$ & $0.54(0.10)$ & $0.52(0.07)$ & $-0.06(0.10)$ \\
\hline Smiltene & $4.25(0.49)$ & $2.88(0.37)$ & $1.15(0.12)$ & $0.57(0.10)$ & $0.63(0.05)$ & $0.06(0.15)$ \\
\hline Šḳēde & $4.88(0.72)$ & $3.02(0.47)$ & $1.17(0.17)$ & $0.49(0.06)$ & $0.61(0.07)$ & $0.15(0.07)$ \\
\hline Glāzšķūnis & $4.00(0.73)$ & $2.43(0.30)$ & $0.99(0.15)$ & $0.64(0.07)$ & $0.55(0.06)$ & $-0.19(0.05)$ \\
\hline Kuprava & $4.63(0.65)$ & $2.83(0.44)$ & $1.11(0.17)$ & 0.57 (0.09) & $0.58(0.08)$ & $-0.01(0.04)$ \\
\hline Gaujiena & $4.63(0.71)$ & $2.91(0.43)$ & $1.14(0.17)$ & $0.52(0.08)$ & $0.60(0.08)$ & $0.14(0.08)$ \\
\hline Ērglii & $4.38(0.68)$ & $2.53(0.30)$ & $1.05(0.13)$ & $0.50(0.05)$ & $0.57(0.06)$ & $0.09(0.05)$ \\
\hline Laidi & $4.25(0.59)$ & $2.75(0.41)$ & $1.06(0.17)$ & $0.53(0.08)$ & $0.57(0.08)$ & $0.03(0.06)$ \\
\hline Saldus & $4.38(0.56)$ & $2.61(0.32)$ & $1.07(0.14)$ & $0.56(0.08)$ & $0.58(0.06)$ & $0.01(0.10)$ \\
\hline Tukums & $3.63(0.42)$ & $2.37(0.29)$ & $0.93(0.14)$ & $0.55(0.10)$ & $0.53(0.07)$ & $-0.06(0.08)$ \\
\hline Rauda & $4.75(0.70)$ & $2.75(0.41)$ & $1.12(0.14)$ & $0.58(0.08)$ & $0.60(0.05)$ & $0.04(0.06)$ \\
\hline Dagda & $4.75(0.73)$ & $2.60(0.33)$ & $1.09(0.15)$ & $0.54(0.07)$ & $0.57(0.06)$ & $0.04(0.04)$ \\
\hline Klauce & $4.50(0.82)$ & $2.80(0.45)$ & $1.08(0.15)$ & $0.60(0.08)$ & $0.60(0.05)$ & $-0.02(0.11)$ \\
\hline Kurmene & $5.50(0.78)$ & $2.81(0.34)$ & $1.19(0.13)$ & $0.55(0.06)$ & $0.62(0.05)$ & $0.08(0.05)$ \\
\hline Jēkabkalns & $4.63(0.38)$ & $2.74(0.30)$ & $1.13(0.10)$ & $0.61(0.07)$ & $0.61(0.05)$ & $-0.01(0.09)$ \\
\hline
\end{tabular}

Na, number of alleles; Ne, number of effective alleles; I, information index; Ho, observed heterozygosity; uHe, unbiased expected heterozygosity; F, inbreeding coefficient; SE, standard error

value, indicating that allele frequencies were more evenly distributed in this population compared to Kurmene. The fixation index (F) ranged from -0.19 (Glāzšḳūnis) to 0.15 (Šḳēde).

The probability of identity, which is the probability that two individuals of a population or sample have the same genotype by chance, over all loci and all populations, was $6.4 \times 10^{-7}$, and for siblings it was $2.8 \times 10^{-3}$. Analysing the probability of identity in each population separately, these values ranged from $1.5 \times 10^{-6}$ in Smiltene $\left(3.3 \times 10^{-3}\right.$ for siblings) to $1.3 \times 10^{-4}$ in Madona $\left(1.9 \times 10^{-2}\right.$ for siblings). A total of ten pairs of individuals were identified with identical multilocus genotypes. Each matching pair was within one population, and these matching genotypes were found in seven populations (Rundāle, Tukums, Glāzšḳūnis, Madona, Limbaži, Klauce, Kurmene).

Unique alleles were found in seven populations (Limbaži, Madona, Kuprava, Ērgḷi, Klauce, Kurmene, Jēkabkalns), with frequencies ranging from 0.021 to 0.364 (average 0.076). The majority of unique alleles were found in the Jēkabkalns population (18 of a total of 27). In addition, almost all unique alleles with a frequency over 0.05 were found in the Jèkabkalns population, with 10 of the 18 unique alleles in this population having a frequency above 0.05 . Analysis of molecular variance (AMOVA) indicated that $9 \%$ of genetic variation was between populations, and $91 \%$ within populations (Fst $=0.088, p<0.001$ ). Pairwise Fst values ranged from 0.009 (Kuprava-Gaujiena) to 0.215 (Madona-Jēkabkalns). Pairwise Nei genetic distances were 


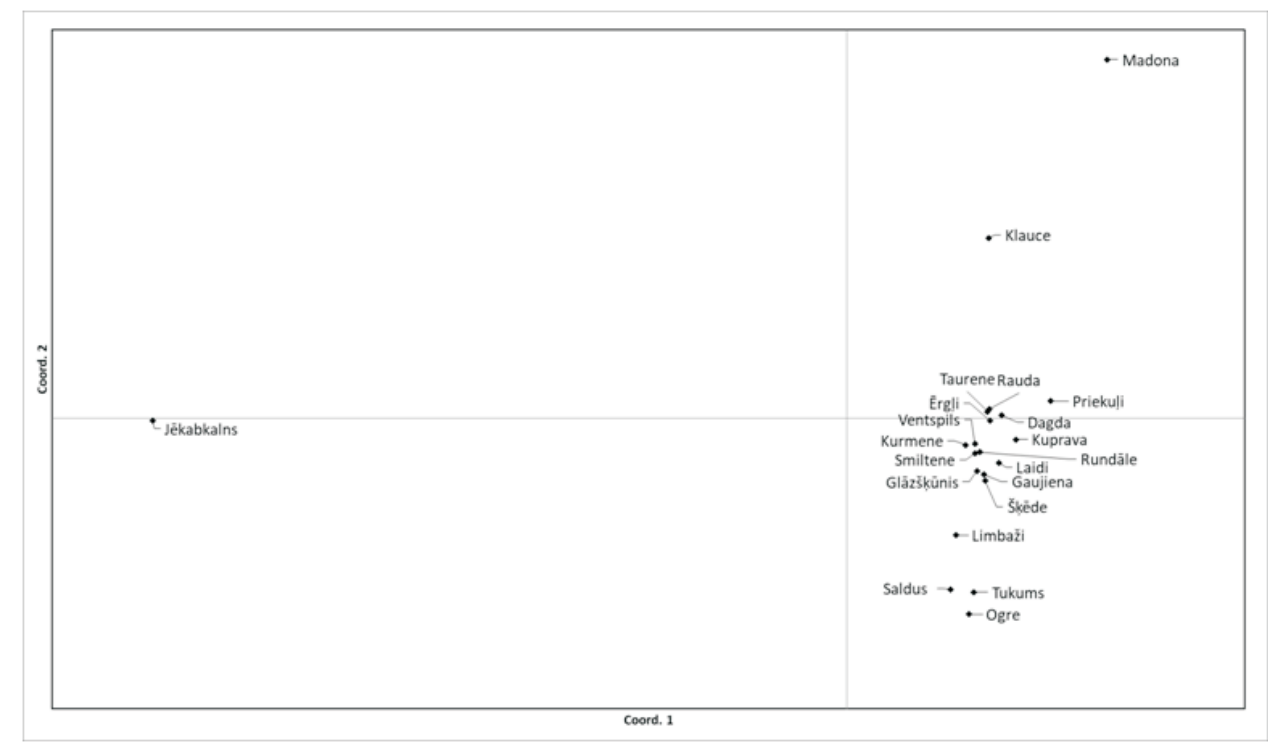

Fig. 2. PCoA of pairwise Nei genetic distances between analysed A. platanoides populations. Percentage of variation explained by axis $1-87.52$, axis $2-4.62$. calculated, and were used to generate a PCoA plot (Fig. 2). Most of the analysed populations were clustered together, with Jēkabkalns being the most distinct, followed by Madona and Klauce. The Saldus, Tukums, and Ogre populations were slightly differentiated from the remaining populations. There was no evidence of higher order structure, either by region (Eastern and Western), or anthropogenic impact (high, medium, low), with AMOVA indicating that differentiation between these groups was low - Fst $=0.01$ $(p<0.001)$ in both cases. Mantel analysis of the pairwise genetic and geographic distance matrices indicted that there was no significant relationship between genetic and geographical distances.

Bayesian clustering was done, taking into account the population of origin of the analysed individuals. This assists clustering in sample sets with low differentiation. Based on the $\Delta \mathrm{K}$ method (Evanno et al.., 2005), the most likely number of clusters was two. Assessing the probability by $\mathrm{K}$ using median values of $\operatorname{Ln}(\operatorname{Pr}$ Data), the $\mathrm{K}$ for which
$\operatorname{Pr}(\mathrm{K}=\mathrm{k})$ was highest and equal to 11 . Graphical display of population structure based on $\Delta \mathrm{K}$ and $\mathrm{K}$ calculated using median values of $\operatorname{Ln}(\operatorname{Pr}$ Data) revealed the probability of each individual to be attributed to one of the studied $A$. platanoides populations in Latvia (Fig. 3). In both cases, the Jēkabkalns population was clearly differentiated from other populations studied. In the case where $\mathrm{K}=11$, the differentiation of other populations was less clear, with individuals having mixed cluster assignment, but Madona population was also differentiated and to a lesser extent the Klauce and Priekuli populations. This corresponds to the PCoA analysis, showing most pronouncedly the differentiation of the Jēkabkalns and Madona populations.

\section{DISCUSSION}

This is the first report of the population genetic analysis of A. platanoides using microsatellite markers. Microsatellite markers have not been developed specifically for A. pla-

$\mathrm{K}=2$

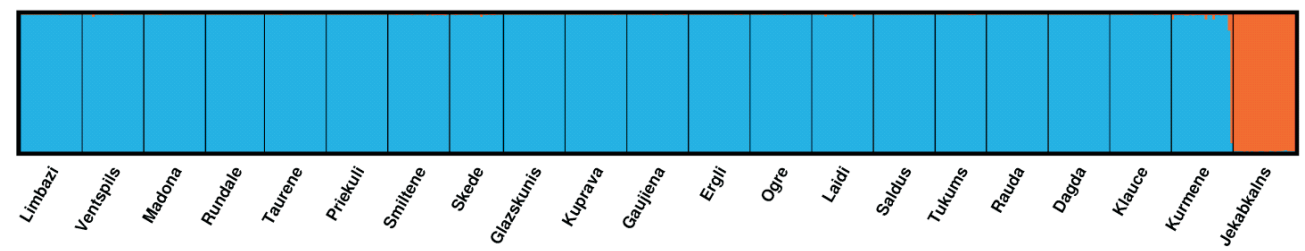

$\mathrm{K}=11$

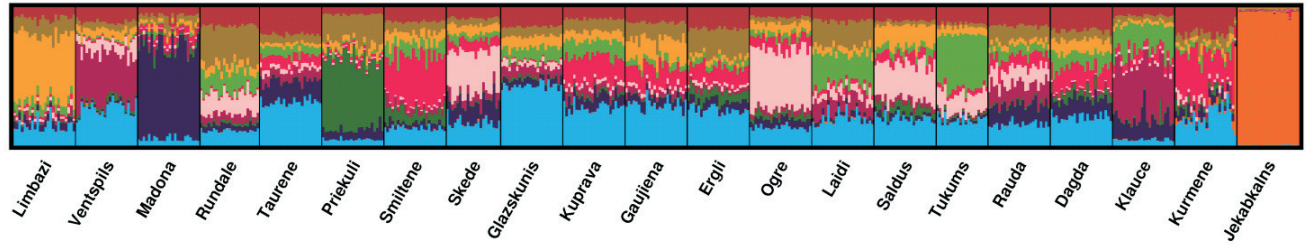

Fig. 3. Plots of coefficients of membership for $\mathrm{K}=2$ the most likely number of clusters as determined by the $\Delta \mathrm{K}$ method and $\mathrm{K}=11$, the most likely number of clusters as determined by the median values of $\operatorname{Ln}(\operatorname{Pr}$ Data). 
tanoides, but can be transferred from related Acer species (Pandey et al., 2004; Saeki et al., 2015; Harmon et al., 2017). In this study, the microsatellite markers developed for sycamore (Acer pseudoplatanus L.) (Pandey et al., 2004) were monomorphic, but the markers derived from sugar maple (Acer saccharum Marsh.) (Harmon et al., 2017) and Acer miyabei Maxim. (Saeki et al., 2015) were polymorphic. These markers revealed a moderate level of polymorphism, the average number of alleles over all loci and populations was 4.38 , and the expected heterozygosity (gene diversity) was 0.58 . There was no convincing evidence for the widespread presence of null alleles, which can occur with the cross-species transfer of microsatellite markers.

The analysed Latvian A. platanoides populations were moderately differentiated $(\mathrm{Fst}=0.088, p<0.001)$, similar to results reported for the isozyme analysis of northern European population (Fst $=0.099)$ (Rusanen et al., 2003). This level of differentiation could be related with insect pollination and wind dispersal of medium sized seeds. The Jekkabkalns population was highly differentiated from all other populations, and had the largest number of unique alleles, the majority of which were of high frequency. The factors causing the higher differentiation of this population is not immediately clear. This population is located in the territory of an old park, with high human impact, and planting of highly differentiated imported germplasm could influence the differentiation of this population. However, there was no direct evidence of former introduction of diversified plant material, and other populations also had a high anthropogenic impact.

Based on the comparison of molecular data, several pairs of individuals with identical multilocus genotypes were found, and each of these pairs were distributed within one population. This indicates that $A$. platanoides can reproduce vegetatively, or that the utilised microsatellite markers do not have sufficient resolution to distinguish genetically distinct individuals. The probability of identity values for siblings was $2.8 \times 10^{-3}$ over all analysed loci and populations, which is not extremely low, so the analysis of additional loci might distinguish these individuals. There are no reports in the scientific literature about the vegetative reproduction of A. platanoides in natural conditions, although rooting of cuttings in glasshouse conditions has been reported (Tomov, 2017). The possibility of vegetative reproduction in natural conditions should be further investigated by detailed spatial analysis of $A$. platanoides stands, and possibly the use of additional genetic markers.

This study provides an initial assessment of the genetic diversity and differentiation of Latvian A. platanoides populations, and is also one of the first reports of the analysis of $A$. platanoides populations using microsatellite markers. Several directions for future investigation were revealed, particularly the investigation of vegetative reproduction in $A$. platanoides, as well as the basis of the high differentiation of the Jēkabkalns population. The results of the current study will enable efficient designation of genetic resource stands, conservation of the genetic diversity of A. platanoides, as well as identification of more differentiated populations.

\section{ACKNOWLEDGEMENTS}

This study was supported by the Latvian-Belarusian cooperation programme research agreement LV-BY/2019/1 "Characterisation of the Latvian and Belarusian smallleaved lime (Tilia cordata Mill.) and Norway maple (Acer platanoides L.) gene pool and utilization to ensure sustainable forestry in changing climatic conditions" funded by the State Education Development Agency of the Republic of Latvia.

\section{REFERENCES}

Carón, M. M., De Frenne, P., Brunet, J., Chabrerie, O., Cousins, S. A., De Backer, L., Diekmann, M., Graae, B. J., Heinken, T., Kolb, A., Naaf, T. (2014). Latitudinal variation in seeds characteristics of Acer platanoides and A. pseudoplatanus. Plant Ecology, 215 (8), 911-925.

Caudullo, G., de Rigo, D. (2016). Acer platanoides in Europe: Distribution, habitat, usage and threats. In: European Atlas of Forest Tree Species. Publications Office of the European Union, Luxembourg, e019159.

Doyle, J., Doyle, J. L. (1990). Isolation of plant DNA from fresh tissue. Focus, 12, 13-15.

Eriksson, G., Black-Samuelsson, S., Jensen, M., Myking, T., Rusanen, M., Skrøppa, T., Vakkari, P., Westergaard, L. (2003). Genetic variability in two tree species, Acer platanoides L. and Betula pendula Roth, with contrasting life-history traits. Scand. J. Forest Res., 18 (4), 320-331.

Evanno, G., Regnaut, S., Goudet, J. (2005). Detecting the number of clusters of individuals using the software STRUCTURE: A simulation study. Mol. Ecol., 14 (8), 2611-2620.

Harmon, M., Lane, T., Staton, M., Coggeshall, M. V., Best, T., Chen, C. C., Liang, H., Zembower, N., Drautz-Moses, D. I., Hwee, Y. Z., Schuster, S. C., Schlarbaum, S. E., Carlson, J. E., Gailing, O. (2017). Development of novel genic microsatellite markers from transcriptome sequencing in sugar maple (Acer saccharum Marsh.). BMC Research Notes, 10 (1), 369.

Kopelman, N. M., Mayzel, J., Jakobsson, M., Rosenberg, N. A., Mayrose, I. (2015). CLUMPAK: A program for identifying clustering modes and packaging population structure inferences across K. Mol. Ecol. Res., 15 (5), 1179-1191.

Pandey, M., Gailing, O., Fischer, D., Hattemer, H. H., Finkeldey, R. (2004). Characterization of microsatellite markers in sycamore (Acer pseudoplatanus L.). Mol. Ecol. Notes, 4 (2), 253-255.

Peakall, R., Smouse, P. E. (2012). GenAlEx 6.5: Genetic analysis in Excel. Population genetic software for teaching and research: an update. Bioinformatics 28, 2537-2539.

Pritchard, J. K., Stephens, M., Donnelly, P. (2000). Inference of population structure using multilocus genotype data. Genetics 155, 945-959.

Rusanen, M., Vakkari, P., Blom, A. (2000). Evaluation of the Finnish gene-conservation strategy for Norway maple (Acer platanoides L.) in the light of allozyme variation. Forest Genet., 7, 155-165.

Rusanen, M., Vakkari, P., Blom, A. (2003). Genetic structure of Acer platanoides and Betula pendula in northern Europe. Canadian J. Forest Res., 33 (6), 1110-1115.

Saeki, I., Hirao, A. S., Kenta, T. (2015). Development and evaluation of microsatellite markers for Acer miyabei (Sapindaceae), a threatened maple species in East Asia. Appl. Plant Sci., 3 (6), 1500020. 
Tomov, V. (2017). Rooting of Norway maple (Acer platanoides L.) Cuttings. Forestry Ideas, 23 (1), 57-64.

Received 11 January 2021

Accepted in the final form 2 July 2021
Van Oosterhout, C., Hutchinson, W. F., Wills, D. P., Shipley, P. (2004). MICRO-CHECKER: Software for identifying and correcting genotyping errors in microsatellite data. Mol. Ecol. Notes 4, 535-538.

\section{LATVIJAS ACER PLATANOIDES POPULĀCIJU STRUKTŪRAS UN DAUDZVEIDĪBAS NOVĒRTĒJUMS, IZMANTOJOT KODOLA MIKROSATELITTU MARĶIERUS}

Acer platanoides L. (parastā kḷava) ir visizplatītākā kḷavu suga Eiropā, kura sastopama no Dienvideiropas un Centrāleiropas līdz Ziemeḷeiropai un Skandināvijai. A. platanoides ir plaši izplatīta visā Latvijas teritorijā, galvenokārt sastopama jauktās platlapju un skujkoku audzēs. Pētījumā analizēta Latvijas A. platanoides populāciju ǵenētiskā daudzveidība un diferenciācija. Populācijas atlasītas visā Latvijas teritorijā un aug dažādos ekoloğiskos apstākḷos ar atškirīgu antropogēnas ietekmes līmeni. Kopumā 496 indivīdi no 21 populācijas tika analizēti ar astoņiem mikrosatelītu marķieriem. Marķieri atklāja mērenu polimorfisma līmeni, un analizētās Latvijas A. platanoides populācijas bija mēreni diferencētas. Šis pētījums sniedz sākotnēju Latvijas A. platanoides populāciju ǵenētiskās daudzveidības un diferenciācijas novērtējumu, kā arī ir viens no pirmajiem ziņojumiem par A. platanoides populāciju analīzi, izmantojot mikrosatelītu markiierus. Rezultātus var izmantot, lai definētu A. platanoides ğenētisko resursu audzes, lai nodrošinātu efektīvu ğenētiskās daudzveidības saglabāšanu. 